\section{Firmness and Aroma Composition of Strawberries following Short-term High Carbon Dioxide Treatments}

\author{
Mette Larsen ${ }^{1}$ and Christopher B. Watkins ${ }^{2}$ \\ The Horticulture and Food Research Institute of New Zealand, Mt Albert \\ Research Centre, Private Bag 92 169, Auckland, New Zealand
}

Additional index words. Fragaria $\times a n a n a s s a$, volatiles, texture

\begin{abstract}
Firmness and aroma composition of strawberry fruit (Fragaria $\times$ ananassa Duch. cv. Pajaro) stored in air or treated with $20 \% \mathrm{CO}_{2}$ for up to 12 days at $0 \mathrm{C}$ were analyzed upon removal from storage. Fruit firmness increased after 2 days in $\mathrm{CO}_{2}$, while the composition of aroma compounds in the fruit was unaffected at this time. Ethanol and ethyl hexanoate accumulated after 3 days during high $\mathrm{CO}_{2}$ treatment, but these compounds usually decreased during subsequent cold storage in air. Ethyl butanoate and ethyl acetate also accumulated but continued to increase after 6 and 9 days of $\mathrm{CO}_{2}$ storage, respectively. This study suggests that treatment of strawberry fruit with $\mathrm{CO}_{2}$ after harvest, followed by air storage at $0 \mathrm{C}$, can maintain firmness while minimizing off-flavor development.
\end{abstract}

Storing strawberries at high $\mathrm{CO}_{2}$ concentrations ( $15 \%$ to $20 \%$ ) maintains firmness and reduces decay of the fruit (Harris and Harvey, 1973; Li and Kader, 1989; Plocharski et al., 1978), and pallet shroud systems for transporting fruit under such conditions are available commercially (Mitchell, 1992). Some studies also show that high $\mathrm{CO}_{2}$ can increase rather than just maintain firmness of strawberries in storage (Plocharski, 1982; Smith, 1992; Smith and Skog, 1992). Residual effects of controlled-atmosphere (CA) storage on fruit quality have been reported; when strawberries were stored for up to 4 days in $20 \% \mathrm{CO}_{2}$ followed by storage in air for a total storage time of 8 days, fruit treated with high $\mathrm{CO}_{2}$ were firmer than controls, and fruit treated with $\mathrm{CO}_{2}$ for 3 or 4 days were firmer than fruit treated for 1 or 2 days (Li and Kader, 1989).

High concentrations of $\mathrm{CO}_{2}$ in the storage atmosphere also favor the accumulation of several volatiles (Guichard et al., 1992; Ke et al., 1991; Li and Kader, 1989; Ueda and Bai, 1993). Some of these volatiles, acetaldehyde, ethyl acetate, and ethanol, correlate with offflavors (Ke et al., 1991), although Larsen and Watkins (1995) found that off-flavors in CAstored strawberries were related to increases in ethyl acetate and ethanol concentrations, but

Received for publication 16 Sept. 1994. Accepted for publication 27 Sept. 1994. This research was supported in part by the Agricultural and Marketing Development Trust, and the Auckland Berryfruit Growers Association. We thank John H. Maindonald for statistical analyses. The cost of publishing this paper was defrayed in part by the payment of page charges. Under postal regulations, this paper therefore must be hereby marked advertisement solely to indicate this fact.

${ }^{1}$ Current address: Centre for Food Research, Royal Veterinary and Agricultural Univ., Thorvaldsensvej 40, 1871 Copenhagan, Denmark.

${ }^{2}$ Current address: Dept. of Fruit and Vegetable Science, Cornell Univ., Ithaca, NY 14853. not acetaldehyde. Ueda and Bai (1993) studied the effects of short-term $\mathrm{CO}_{2}$ treatments and found an immediate increase in the production of ethyl acetate and ethyl butanoate associated with an "unnatural" aroma. Guichard et al. (1992) studied the aroma composition of strawberries after storage at high $\mathrm{CO}_{2}$ concentrations and found that the level of all ethyl esters increased strongly under these conditions. However, the relationships between the various aroma compounds in response to $\mathrm{CO}_{2}$ are not clear, and yet these may greatly influence the quality of the fruit. For example, ethyl acetate is associated with the formation of an anaerobic off-flavor (Larsen, 1994), but ethyl butanoate and ethyl hexanoate have pleasant, fruity flavors. Our objective was to inves- tigate the effects of high $\mathrm{CO}_{2}$ treatment on firmness and aroma composition of 'Pajaro' strawberries, either held in this treatment or in subsequent air storage.

\section{Materials and Methods}

'Pajaro' strawberries were obtained from a commercial grower in the Auckland area. Damaged, unripe ( $<50 \%$ red surface), and overripe fruit were discarded. Fruit were allocated randomly to $1-\mathrm{kg}$ samples ( $\approx 50$ berries) and stored at $0 \mathrm{C}$ in 27-liter chambers, each holding two samples. Precision needle valves were used to mix $\mathrm{CO}_{2}$ and air to produce a $20 \%$ $\mathrm{CO}_{2}$ atmosphere. Control samples were flushed with air. The gas mixture and air were bubbled through water at $0 \mathrm{C}$ to obtain vapor saturation, and passed through each chamber at 200 $\mathrm{ml} \cdot \mathrm{min}^{-1}$. Carbon dioxide concentrations in the chambers were verified by gas chromatography.

Samples were stored for 1, 2, 4, 6, 9, and 12 days. Upon removal from chambers, one sample from each chamber was transferred to air at 20C and analyzed after $4 \mathrm{~h}$ of temperature equilibration. The other sample was transferred to air at $0 \mathrm{C}$ and analyzed after 12 days of storage.

Firmness was assessed on two replicates of eight fruit from each treatment by measuring the maximum shear force required for tissue failure. Horizontal slices $6 \mathrm{~mm}$ thick were cut from the broadest part of the fruit, and onequarter of each of these eight slices was placed in a Kramer shear cell of an Instron model 4301 materials testing machine (Instron, Canton, Mass.) fitted with a 5-kN load cell. The crosshead speed was $100 \mathrm{~mm} \cdot \mathrm{min}^{-1}$. Two measurements were carried out per replicate. Firmness values were divided by the tissue weight to correct for differences in the area of tissue bisected by the plates of the shear cell.

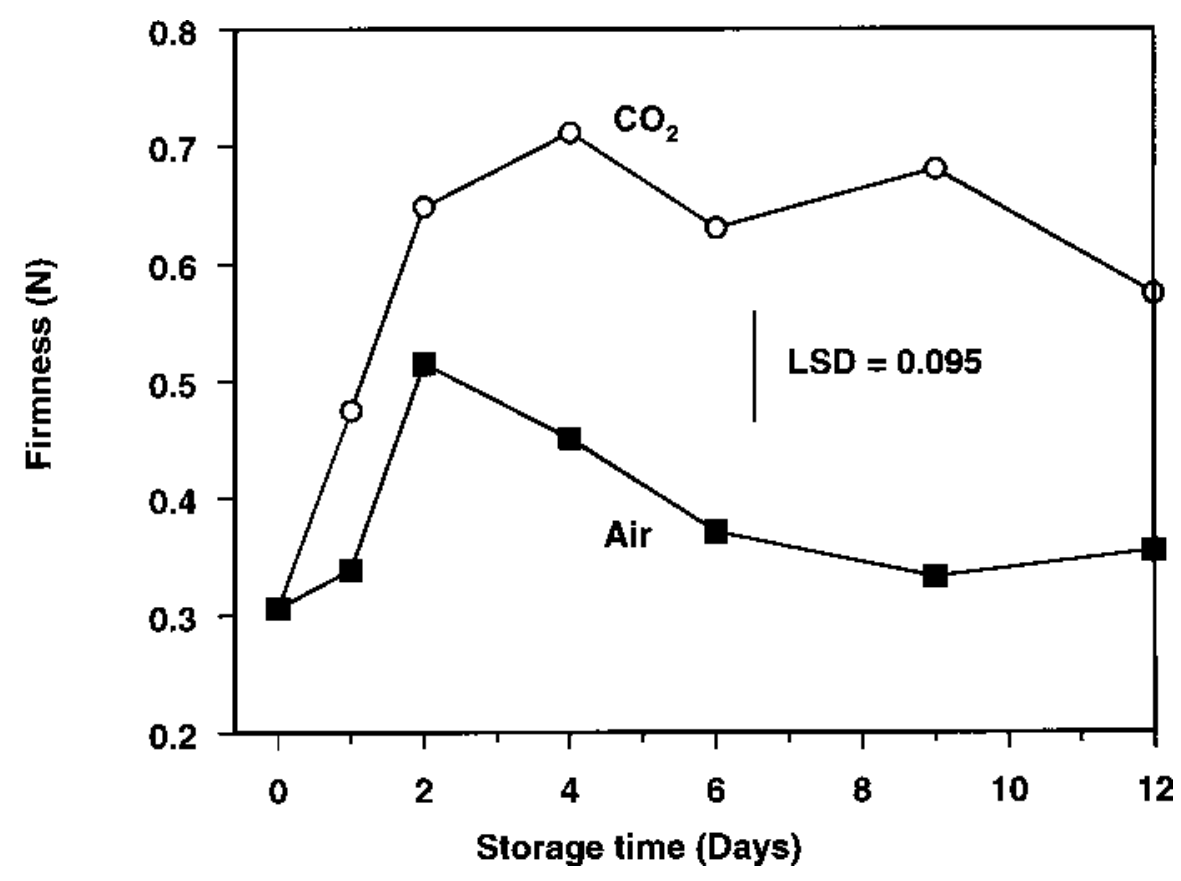

Fig. 1. Firmness (N) of 'Pajaro' strawberries stored in ( $\mathbf{\square})$ air or in $(\mathrm{O}) 20 \% \mathrm{CO}_{2}$ for up to 12 days. 
For analysis of aroma compounds, $300 \mathrm{~g}$ of fruit from each sample was homogenized in a Waring blender for $30 \mathrm{sec}$ (low speed). Duplicate 5-g samples of homogenate were transferred to $20-\mathrm{ml}$ vials with septum lids and stored at $-20 \mathrm{C}$. For subsequent analysis, samples were incubated at $40 \mathrm{C}$ for $20 \mathrm{~min}$; then, 1-ml headspace samples (in triplicate) were analyzed at 50C in a HP5890 gas chromatograph (Hewlett-Packard, Delaware) equipped with a DBWAX column $(30 \mathrm{~m} \times$ $0.53 \mathrm{~mm} \times 1 \mu \mathrm{m})$ and a flame ionization detector.

Other strawberry aroma compounds were extracted from duplicate $20 \mathrm{~g}$ samples of homogenate with $20 \mathrm{ml}$ diethyl ether and concentrated as described by Larsen and Poll (1990). An internal standard of $400 \mu 1$ of 50 ppm 4-methyl-1-pentanol solution was added to the homogenate. Concentrated extracts were analyzed in triplicate by gas chromatography as above using the following temperature program: $50 \mathrm{C}$, for $5 \mathrm{~min} ; 10 \mathrm{C} / \mathrm{min}$ until $200 \mathrm{C}$; $200 \mathrm{C}$, for $25 \mathrm{~min}$. All compounds were identified on the basis of their retention times, and amounts relative to the internal standard were quantified by using a range of standards of the compounds (in water).

Differences in aroma composition at harvest and after storage in air or $\mathrm{CO}_{2}$ for 12 days were assessed using least significant differences based on Tukey's Studentized range or w statistic (Steel and Torrie, 1981). Concentrations of the compounds were transformed to logarithms to reduce variance before analysis. Values for ethyl butanoate were analyzed without transformation because transformation increased variance differences. For the remaining compounds, 0.01 was added before taking logarithms, to accommodate zeros. A consequence of logarithm use is that the least significant differences (LSD) gave a ratio of larger to smaller values. Where the ratio was greater than the LSD, values were significantly different. Orthogonal polynomials were used to study changes with time, partitioning the sums of squares into components that were associated, successively, with linear, quadratic, and cubic terms (Steel and Torrie, 1981).

\section{Results and Discussion}

The firmness of strawberries from $20 \%$ $\mathrm{CO}_{2}$ was higher than that of the air control fruit (Fig. 1), the average benefit of $\mathrm{CO}_{2}$ treatment over air treatment being $0.23 \mathrm{~N}$ during the 12 days of storage. The relationship of the $\mathrm{CO}_{2}$ effect against time was quadratic $(P<0.05)$, and the maximum effect of $\mathrm{CO}_{2}$ on enhancing firmness was obtained within 2 days of treatment. Fruit held in air, without $\mathrm{CO}_{2}$ treatment, appeared to be initially firmer after 2 days than at harvest, but the effect was not statistically significant. Fruit transferred from $\mathrm{CO}_{2}$ treatment to air after 2, 4, 6, and 9 days did not change in firmness after a total storage period of 12 days (data not shown), providing further evidence of the residual effect of CA storage as suggested by Li and Kader (1989).

Concentrations of acetaldehyde, ethyl acetate, ethanol, ethyl butanoate, ethyl hexanoate, and acetic acid increased substantially during treatment with $\mathrm{CO}_{2}$. Acetic acid concentrations also increased during air storage. Trans2-hexenal, $\gamma$-decalactone, and butanoic acid remained constant during either air or $\mathrm{CO}_{2}$ storage, while hexyl acetate, methyl hexanoate, 2-methyl propanoic acid, 2-methyl butanoic acid, and hexanoic acid decreased during treatment with $\mathrm{CO}_{2}$ (Table 1). 2,5-Dimethyl-4methoxy-3(2H)-furanone and 2,5-dimethyl4-hydroxy-3 $(2 \mathrm{H})$-furanone increased during both air and $\mathrm{CO}_{2}$ storage.

Concentrations of ethyl acetate, ethyl butanoate, ethyl hexanoate, and ethanol began to increase appreciably after 4 days or more of $\mathrm{CO}_{2}$ treatment (Table 2), in a fashion similar to that reported by Guichard et al. (1992). After transfer to air storage, the concentrations of ethyl acetate, ethyl hexanoate, and ethanol in the fruit generally decreased, whereas those of ethyl butanoate generally increased (Table 2). However, ethyl acetate increased in air after an initial 9 days of $\mathrm{CO}_{2}$ treatment. Ueda and Bai (1993) reported high accumulations of ethyl

Table 1. Aroma composition $\left(\mathrm{mg} \cdot \mathrm{kg}^{-1}\right)$ of strawberries at harvest and after 12 days of storage in air or $20 \%$ $\mathrm{CO}_{2}$ at $0 \mathrm{C}$.

\begin{tabular}{lcccc}
\hline & & \multicolumn{2}{c}{ Stored 12 days } & LSD \\
Compound & At harvest & Air & $20 \% \mathrm{CO}_{2}$ & (as a ratio) $^{\mathrm{y}}$ \\
\hline Acetaldehyde & $2.1 \mathrm{~b}^{\mathrm{z}}$ & $3.0 \mathrm{~b}$ & $13.8 \mathrm{a}$ & 1.80 \\
Ethyl acetate & $0.14 \mathrm{c}$ & $1.0 \mathrm{~b}$ & $84.0 \mathrm{a}$ & 1.68 \\
Ethanol & $11.0 \mathrm{~b}$ & $19.0 \mathrm{~b}$ & $366.0 \mathrm{a}$ & 2.04 \\
Ethyl butanoate & $0.1 \mathrm{~b}$ & $0.5 \mathrm{~b}$ & $10.3 \mathrm{a}$ & $2.40^{\mathrm{x}}$ \\
Ethyl hexanoate & $0.00 \mathrm{~b}$ & $0.00 \mathrm{~b}$ & $0.59 \mathrm{a}$ & 1.49 \\
Hexyl acetate & $0.2 \mathrm{a}$ & $0.00 \mathrm{~b}$ & $0.00 \mathrm{~b}$ & 1.32 \\
Methyl hexanoate & $0.37 \mathrm{a}$ & $0.00 \mathrm{~b}$ & $0.00 \mathrm{~b}$ & 1.23 \\
Trans-2-hexenal & $10.5 \mathrm{a}$ & $9.7 \mathrm{a}$ & $9.2 \mathrm{a}$ & 1.44 \\
$\gamma$-decalactone & $0.34 \mathrm{a}$ & $0.24 \mathrm{a}$ & $0.17 \mathrm{a}$ & 4.72 \\
2,5-Dimethyl-4-methoxy-3(2H)-furanone & $2.6 \mathrm{~b}$ & $10.7 \mathrm{a}$ & $15.2 \mathrm{a}$ & 1.79 \\
2,5-Dimethyl-4-hydroxy-3(2H)-furanone & $3.9 \mathrm{~b}$ & $21.1 \mathrm{a}$ & $13.9 \mathrm{a}$ & 1.64 \\
Acetic acid & $22.1 \mathrm{c}$ & $48.3 \mathrm{~b}$ & $251 \mathrm{a}$ & 1.54 \\
2-Methyl propanoic acid & $0.93 \mathrm{a}$ & $0.66 \mathrm{ab}$ & $0.42 \mathrm{~b}$ & 1.57 \\
2-Methyl butanoic acid & $3.9 \mathrm{a}$ & $2.8 \mathrm{a}$ & $1.7 \mathrm{a}$ & 3.00 \\
Butanoic acid & $0.21 \mathrm{a}$ & $0.14 \mathrm{a}$ & $0.15 \mathrm{a}$ & 2.26 \\
Hexanoic acid & $1.0 \mathrm{a}$ & $1.1 \mathrm{a}$ & $0.5 \mathrm{~b}$ & 1.36
\end{tabular}

${ }^{2}$ Mean separation within a row by Tukey's Studentized range test on the transformed values $(P<0.05)$.

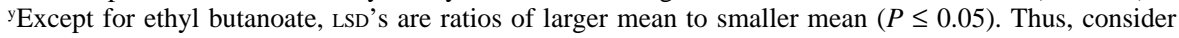
acetaldehyde: As $3 / 2.1$ is $<1.8$, the air and at harvest results cannot be distinguished. Because $13.8 / 2.1$ and $13.8 / 3$ are $>1.8$, the $20 \% \mathrm{CO}_{2}$ result can be distinguished from the other two. Where one of the means is zero, it is necessary to add 0.01 before taking the ratio.

${ }^{x}$ For ethyl butanoate, the absolute difference is used for comparison.

Table 2. Ethyl acetate, ethyl butanoate, ethyl hexanoate, and ethanol concentrations $\left(\mathrm{mg} \cdot \mathrm{kg}^{-1}\right)$ in strawberry fruit during treatment with $20 \% \mathrm{CO}_{2}$ at $0 \mathrm{C}$ and after subsequent cold storage. Fruit were stored under $20 \% \mathrm{CO}_{2}$ for $0,1,2,4,6,9$ or 12 days, and assessed immediately or after cold storage for a total storage period of 12 days.

\begin{tabular}{|c|c|c|c|c|c|c|}
\hline \multirow{2}{*}{\multicolumn{2}{|c|}{$\begin{array}{c}\text { Duration of } \\
\text { storage (days) }\end{array}$}} & \multicolumn{5}{|c|}{ Concn $\left(\mathrm{mg} \cdot \mathrm{kg}^{-1}\right)$} \\
\hline & & \multirow{2}{*}{$\begin{array}{c}\text { Ethyl } \\
\text { acetate }\end{array}$} & \multirow{2}{*}{$\begin{array}{c}\text { Ethyl } \\
\text { butanoate }\end{array}$} & \multirow{2}{*}{\multicolumn{2}{|c|}{$\begin{array}{c}\text { Ethyl } \\
\text { hexanoate }\end{array}$}} & \multirow[b]{2}{*}{ Ethanol } \\
\hline With $20 \% \mathrm{CO}_{2}$ & Total & & & & & \\
\hline 0 & 0 & 0.10 & 0.10 & & & 10.8 \\
\hline 0 & 12 & 1.0 & 0.50 & & & 19.1 \\
\hline 1 & 1 & 0.47 & 0.33 & & & 6.9 \\
\hline 1 & 12 & 0.24 & 0.90 & & & 7.4 \\
\hline 2 & 2 & 1.5 & 0.45 & & & 12.4 \\
\hline 2 & 12 & 0.20 & 0.80 & & & 8.0 \\
\hline 4 & 4 & 17.1 & 1.5 & & & 47.4 \\
\hline 4 & 12 & 4.8 & 0.57 & & & 10.2 \\
\hline 6 & 6 & 34.7 & 2.3 & & & 108 \\
\hline 6 & 12 & 20.5 & 7.6 & & & 27.4 \\
\hline 9 & 9 & 66.7 & 2.9 & & & 231 \\
\hline 9 & 12 & 99.5 & 10.0 & & & 160 \\
\hline 12 & 12 & 83.6 & 10.3 & & & 367 \\
\hline $\mathrm{LSD}^{\mathrm{Z}}$ & & 1.54 & 1.37 & & & 1.18 \\
\hline \multicolumn{7}{|c|}{ Orthogonal polynomial components: } \\
\hline \multicolumn{7}{|c|}{ 1) $\mathrm{CO}_{2}$ storage only (rows $1,3,7,9,11$ ) } \\
\hline Linear & & & $<0.0001$ & $<0.001$ & $<0.001$ & $<0.0001$ \\
\hline Quadratic & & & $<0.001$ & NS & $<0.02$ & NS \\
\hline Cubic & & & NS & $<0.05$ & $<0.02$ & $<0.01$ \\
\hline \multicolumn{7}{|c|}{ 2) $\mathrm{CO}_{2}$ plus air storage (rows $2,4,6,8,10,12$ ) } \\
\hline Linear & & & $<0.0001$ & $<0.001$ & $<0.001$ & $<0.0001$ \\
\hline Quadratic & & & $<0.0001$ & NS & $<0.05$ & $<0.0001$ \\
\hline Cubic & & & $<0.0001$ & $<0.01$ & $<0.05$ & $<0.0001$ \\
\hline
\end{tabular}

${ }^{{ }_{\mathrm{LSD}}}$ for comparing means under $\mathrm{CO}_{2}$ storage only with $\mathrm{CO}_{2}$ plus air storage. Except for ethyl butanoate, means that differ by more than this ratio are significantly different, $t$ test, $P=0.05$. See footnote of Table 1 for explanation. (For ethyl butanoate, it is the absolute difference that matters.) 
acetate and ethyl butanoate in fruit stored in $20 \% \mathrm{CO}_{2}$ at $1 \mathrm{C}$ for $12 \mathrm{~h}$. They also noted that the ethyl ester continued to accumulate in fruit stored for $24 \mathrm{~h}$ in $20 \% \mathrm{CO}_{2}$ and then transferred to air.

Accumulation of individual ethyl esters was variable under the same conditions, and such changes may affect the flavor of the fruit. Informal taste tests indicated that the presence of off-flavors was consistent with changes in aroma compound concentrations. Off-flavors developed after 4 days of high $\mathrm{CO}_{2}$ storage, but they disappeared when fruit was subsequently held in air for a few days. Only slight offflavors were detected in fruit stored for 6 days at high $\mathrm{CO}_{2}$ plus 6 days in air, although the ethyl acetate content in this fruit was similar to that of fruit evaluated after 4 days of high $\mathrm{CO}_{2}$ storage. However, the ethyl butanoate content had increased markedly in samples stored for 6 days under high $\mathrm{CO}_{2}$ and 6 days in air. This compound has a pleasant, fruity flavor and a low odor threshold and is one of the characteristic compounds of some strong-flavored strawberry cultivars, whereas it is scarce or absent in more weakly flavored cultivars (Larsen et al. 1992). As the threshold values of ethyl butanoate and ethyl hexanoate are very low compared to the threshold value of ethyl acetate (Larsen and Poll, 1992), formation of smaller amounts of ethyl butanoate and ethyl hexanoate might improve flavor quality. Thus, in our experiments, the higher ethyl butanoate content may have contributed to pleasant flavors that masked the off-flavor due to ethyl acetate in the fruit stored in air for 6 days after 6 days of $\mathrm{CO}_{2}$ treatment. Variation in production of individual ethyl esters under the same treatment conditions may improve flavor qual- ity. This study suggests that treatment of strawberry fruit with $\mathrm{CO}_{2}$ after harvest, followed by air storage at $0 \mathrm{C}$, can maintain flesh firmness while minimizing off-flavor development. Further research is needed to determine the CA conditions that result in optimally flavored fruit.

\section{Literature Cited}

Guichard, E., Y. Chambroy, M. Reich, N. Fournier, and M. Souty. 1992. Influence de la concentration en dioxyde de carbone sur la qualité aromatique des fraises aprèsentreposage. Sci. Aliments 12:83-100.

Harris, C.M. and J.M. Harvey. 1973. Quality and decay of California strawberries stored in $\mathrm{CO}_{2-}$ enriched atmospheres. Plant Dis. Rptr. 57:4446.

Ke, D., L. Goldstein, M. O'Mahoney, and A.A. Kader. 1991. Effects of short-term exposure to low $\mathrm{O}_{2}$ and high $\mathrm{CO}_{2}$ atmospheres on quality attributes of strawberries. J. Food Sci. 56:5054.

Larsen, M. 1994. Volatile compounds formed in strawberries under anaerobic conditions and their influence on off-flavour formation, p. 421-424. In: H. Maarse and D.G. van der Heij (eds.). Trends in flavour research. Proc. 7th Weurman Flavour Res. Symp., Noordwijkerhaut, The Netherlands, 15-18 June 1993. Elsevier, Amsterdam.

Larsen, M. and L. Poll. 1990. Quick and simple extraction methods for analysis of aroma compounds in fruit products, p. 209-212. In: A.F. Thomas and Y. Bessière (eds.). Flavor science and technology. Wiley, New York.

Larsen, M. and L. Poll. 1992. Odour thresholds of some important aroma compounds in strawberries.Zeitschrift fuer Lebensmittel-Untersuchung und Forschung 195:120-123.

Larsen, M., L. Poll, and C.E. Olsen. 1992. Evaluation of the aroma composition of some straw- berry (Fragaria ananassa Duch) cultivars by use of odour threshold values. Zeitschrift fuer Lebensmittel-Untersuchung und Forschung 195:536-539.

Larsen, M. and C.B. Watkins. 1995. Firmness and concentrations of acetaldehyde, ethyl acetate and ethanol in strawberries stored in controlled and modified atmospheres. Postharvest Biol. Technol. 5:39-50.

Li, C. and A.A. Kader. 1989. Residual effects of controlled atmospheres on postharvest physiology and quality of strawberries. J. Amer. Soc. Hort. Sci. 114:629-634.

Mitchell, F.G. 1992. Postharvest handling systems: Small fruits (table grapes, strawberries, kiwifruit), p. 223-231. In: A.A. Kader (ed.). Postharvest technology of horticultural crops. 2nd ed. Univ. of California Publ. 3311, Oakland.

Plocharski, W. 1982. Strawberries-Quality of fruits, their storage life and suitability for processing. Part III. Firmness and pectic substance changes of strawberries stored under normal and controlled atmosphere conditions. Fruit Sci. Rpt. 9:111-122.

Plocharski, W., E. Lange, and W. Lenartowicz. 1978. Strawberries-Quality of fruits, their storage life and suitability for processing. Part II. Changes in strawberry quality in relation to storage conditions. Fruit Sci. Rpt. 5:47-55.

Smith, R.B. 1992. Controlled atmosphere storage of 'Redcoat' strawberry fruit. J. Amer. Soc. Hort. Sci. 117:260-264.

Smith, R.B. and L.J. Skog. 1992. Postharvest carbon dioxide treatment enhances firmness of several cultivars of strawberry. HortScience 27:420421.

Steel, R.G.D. and J.H.Torrie 1981. Principles and procedures of statistics. A biometrical approach McGraw-Hill, New York.

Ueda, Y. and J.H. Bai. 1993. Effect of short-term exposure of elevated $\mathrm{CO}_{2}$ on flesh firmness and ester production of strawberry. J. Jpn. Soc. Hort. Sci. 62:457-464. 